\title{
Multi-focal Analysis of Workplace Spirituality and Employee Commitment: Exploratory Empirical
}

\author{
Assessment \\ Mohamed Fares Brini \\ Faculty of Economics and Management of Nabeul \\ University of Carthage (Tunisia)
}

Received: Dec. 21, 2020 Accepted: Jan. 15, 2021 Online published: Jan. 28, 2021

doi:10.5296/ijhrs.v11i1.18096

URL: https://doi.org/10.5296/ijhrs.v11i1.18096

\begin{abstract}
The purpose of this paper was to examine the contribution of workplace spirituality to employee commitment from a multi-focal perspective at the individual, group and organizational levels. Obtained data from a random sample of 111 Tunisian employees were analysed using PLS-SEM to test the proposed hypothesis of the study. The findings revealed that three-dimensional workplace spirituality (meaningful work, sense of community and organizational values) contributed positively and significantly to multiple commitment levels (individual, group and organization levels). Besides, these spiritual dimensions contributed to more than one level and showed that workplace spirituality framework can provide an expanded contribution to the multiple commitment research. In particular, meaningful work had the largest contribution to all commitment levels and can offer unique approach to manage overall commitment within organizations.
\end{abstract}

Keywords: workplace spirituality, employee commitment, multi-focal analysis

\section{Introduction}

In light of the enduring transformations of work and employment relationships, the psychological bonds of employees within their organizations have changed and challenged companies and employees to reconsider their commitment strategy (Meyer, 2016; Singhal \& Chatterjee, 2006; Van Rossenberg et al., 2018). Thus, employee commitment continues, to this day, to trigger the present and future of work employment relationships, and therefore needs a thorough consideration. In particular, the contemporary work context has renewed the interest in commitment research by emphasizing the importance of its multiple forms and targets. For instance, temporary and cross-boundary work have expanded the targets of commitment from one singular target (i.e., the organization) to multiple targets either internal 
(e.g., colleagues, teams, job) or external (e.g., other organizations, customers, professions, careers). Yet, this multiplicity often led to conflicting bonds and commitments which may result from the incompatibility of multiple goals and values percieved by employees in the presence of different targets in the work environment (Klein et al., 2012; Van Rossenberg et al., 2018).Thus, companies should be aware of the complexities induced by these work changes to accept and then adequately manage the coexistence of these different commitments within one single company without hindering overall commitment. Consequently, the complex nature of commitment in modern organizations invites us to understand each employee' $s$ interests and needs to determine and develop more adequate commitment orientation and strategy (Meyer, 2016). Besides, and in response to these changes, an interest has been adressed to the study of workplace spirituality. This research stream has initially focused on the impact of modern work transformations and how individuals in consequence become looking to their work and organization to achieve high-order needs, accomplish interesting and meaningful work and nurture their fundamental self-concept (Ashmos \& Duchon, 2000; Duchon \& Plowman, 2005; Mitroff, 2003). Indeed, several studies have shown the benefits of value and spiritual-based environment to foster the humanness of the work environment (Dhiman \& Marques, 2011; Wagner-Marsh \& Conley, 1999) and create favourable conditions for identification, psychological well-being and positive work-related attitudes and behaviours (e.g., organizational identification, organizational commitment, organizational performance, etc.) (Milliman et al., 2003). For instance, Milliman et al. (2017) suggested that research on workplace spirituality can provide a convenient framework to assess more adequately the psychological interplay and fit of individuals with their work environment and their company. Accordingly, similar to person-environment fit framework (Kristof-Brown et al., 2005), they proposed a spiritual multifocal framework, comprising the individual, group and organizational levels, with an emphasize on the spiritual and higher-order needs as regarding to different constituents of the workplace (job, team, colleagues, company, etc.).

The present study aims to contribute to this research stream by examining the impact of three-dimensional workplace spirituality (meaningful work, sense of community and organizational values) on specific employee commitments at the individual, group and organizational levels. To this end, a multifocal framework integrating these spiritual dimensions was presented to establish their links with multiple commitment foci. Next, subsequent hypotheses will be tested using a PLS-SEM analysis. Finally, implications and directions for future research are given with regard to the findings.

\section{Theoretical Background and Hypothesis Development}

\subsection{Employee Commitment and Workplace Spirituality in Today's Workplace}

Employee commitment continues to be an important psychological concept in most organizational studies and in employment relationships in particular (Meyer, 2016). According to Klein et al. (2012), employee commitment refers to a psychological bond with one or more targets of a work setting (e.g., organization, colleagues, job, supervisor, etc.). Accordingly, the whole organization was first considered as a privileged target to which an 
individual feels emotionally attached and identified, in addition to a strong desire to maintain its membership within it (Mowday et al., 1979). This approach of commitment has been referred to as the attitudinal or affective view of commitment (Meyer \& Allen, 1991). Besides, commitment was viewed as a multidimensional concept involving, in addition to the affective component, two other components known as the continuance commitment referring to the perceived costs of leaving the organization; and the normative commitment, which refers to the obligation to stay in the organization (Meyer \& Allen, 1991). Finally, commitment was also studied as a multiple foci or target concept, suggesting that employees might be committed to one or various targets at a time within or outside the company (Meyer et al., 2002).

Yet, in practice, maintaining and achieving long-term commitment in today's workplace becomes a challenging issue. For instance, many employees may have multiple and unstable bonds with different targets and hence may experience their attachment to each one differently (Klein et al., 2012). As explained by Cohen (2003, p. 5), several factors have pushed employees to reconsider their commitment orientation. For example, changes in employment practices and relationships to gain more flexibility and efficiency (e.g., downsizing, layoffs, mergers, etc.), have reduced the degree of commitment towards the company and raised instead the importance of other forms such as career-oriented and occupation-oriented commitment (e.g., professional commitment). These employees would search for more fulfilling and exiting life-long employment. Besides, new management styles based on teamwork increased the interest in high-qualities interrelationships and hence other types of commitment such as group-oriented commitment. Thus, employees can develop different psychological bonds at the workplace at the same time and other targets besides the company may be more or less desirable (Knapp et al., 2020). In support for this assumption, several scholars referred to the self-concept and identity-based theory of commitment, which linked specific work-related attitudes and behaviours to the identity definition and level of individuals (Burke \& Reitzes, 1991; Oyserman, 2007; Shamir, 1991). For instance, Johnson and Chang (2006) and Johnson et al. (2010) explained that specific types of commitment within the company varied according to the identiy level (e.g., individual, relational or collective) and the contextual information processed by the individuals. For example, employees with an individual-based identity were more focused on self-interested outcomes (job recognition, respect, career development) whereas relational- or collective-based individuals were focused on group-interested outcomes (group welfare, social and collective interests, quality of interrelationships). Likewise, Klein et al. (2012) and Greguras and Diefendorff (2009) found that individuals perceive their work environement in different matters and at different levels and hence may choose different commitment targets and orientations. Similarly, employees tend to manifest specific attitudes and behaviours given their self-concept (Brewer \& Gardner, 1996; Lapointe et al., 2019) and therefore can perform better in a workplace where they can completely understand and define themselves according to their needs and expectations whether concerning their job, group or the company as a whole (Duchon \& Plowman, 2005).

In the same vein, an interest in the study of Workplace Spirituality (WS) has followed the 
rapid change of work and employment relationships and raised the importance of the fundamental and higher-order employees' needs at the workplace (Ashmos \& Duchon, 2000). In fact, business leaders have acknowledged the need for a new business paradigm for the workplace which directly embraces spiritual needs (e.g., meaning, transcendence, community) above material concerns (e.g., salary, working hours, etc.) (Ashar \& Lane-Maher, 2004; Delbecq, 2013; Gull \& Doh, 2004; Neal, 2000; Van Den Heuvel et al., 2009). Indeed, current workplace transformations have added more pressure on employees and so forth more emotional and spiritual competencies are deemed important (Dehler \& Welsh, 1994). Conjointly, the workplace becomes an opportunity for individuals to search for meaning and purpose in their life (Ashmos \& Duchon, 2000; Mitroff \& Denton, 1999) and transcend to a more personal and spiritual growth (Krahnke et al., 2003). Overall, the workplace spirituality framework can ultimately be viewed as the joint study of the individual self and the work environment with a focus on spiritual needs such as the search for meaning and belonging through the experience of work at the individual, group and organizational levels (Duchon \& Plowman, 2005; Milliman et al., 2017; Shamir, 1991).

Consequently, the contemporary view of today's workplace will require a further understanding of multiple commitment targets and determinants and therefore a better screening of the psychological orientation and needs of employees with regard to these different targets (Cohen, 2003; Johnson \& Chang, 2006; Van Rossenberg et al., 2018). The next section will provide further insight to this research avenue by exploring the contributing role of workplace spirituality to employee commitment from a multifocal standpoint.

\subsection{A Multi-Focal Framework Linking Workplace Spirituality to Employee Commitment}

As discussed above, the contemporary view of the workplace has suggested that employee commitment can no longer be viewed as a single commitment type nor oriented towards one unique target (Cohen, 2003; Klein et al., 2012). Therefore, it can be assumed that employee commitment can be of various types and targets that rise in importance given specific workplace conditions. In order to explore this multifocal nature of commitment and workplace characteristics, the present paper used the spiritual framework developed by Ashmos and Duchon (2000, p. 137) which was defined as "the recognition that employees have an inner life that nourishes and is nourished by meaningful work that takes place in the context of community". In a recent empirical reviews (Benefiel et al., 2014; Houghton et al., 2016; Joelle \& Coelho, 2019), the Ashmos and Duchon (2000)'s framework was recognized as showing large acceptance and consistency (Houghton et al., 2016, p. 5). In particular, it has enabled the adoption of three-level workplace dimensions (individual, group and organizational) and showed its adequacy in the study of different employee work attitudes such as job satisfaction, job involvement and employee commitment in general. Besides, Benefiel et al. (2014) and Houghton et al. (2016, p. 14) recommended that future research should further explore whether workplace spirituality may have different effects at various levels of analysis. Therefore, the use of this framework as a basis for explaining employee commitment can further enhance the understanding of its multifaceted and multilevel nature.

This framework described the workplace based on three spiritual dimensions, which are 
meaningful work, sense of community and organizational values, examined at three different levels, individual, group and organizational levels, respectively. Hence, based on this framework, the present study posits the following hypotheses which linked each spiritual dimension to three specific commitment targets (hereafter, job involvement, group commitment and organizational commitment) measured at the individual, group and organizational levels:

\subsubsection{Individual Level: Meaningful Work and Employee Commitment}

Central to the definition of WS is the dimension of meaningful work which posits that the experience of work conveys to the employee feelings of joy and contribution and constitutes a source of meaning and purpose in life (Ashmos \& Duchon, 2000; Milliman et al., 2003). Guevara and Ord (1996, p. 713) asserted that the realm of work provides for individuals the opportunities to derive meaning around three main spheres, i.e., contribution, belonging and relationship. Individuals want to perceive a positive value and impact of their job and how this contributes to their relations to others, the group and the organization. According to the authors, if none of this is possible in the context of work, individuals will feel disoriented, depressed and this will impact their ability to perform well. Pratt and Ashforth (2003) asserted too that the meaningfulness of work is based on a meaning in work (the direct attributes of the job) and a meaning at work (membership and belonging). Besides, several authors argued that some employees look up to their job as something they could create and craft by themselves in order to be meaningful (Wrzesniewski \& Dutton, 2001). Hence, according to Duchon and Plowman (2005) and Milliman et al. (2017), this particular spiritual dimension, evaluated at the individual level, expands the limits of job-design literature to embrace higher-order values of one's work such as the sense of calling, transcendence, service to others and conncecting to larger good and important things in life (Krahnke et al., 2003; Neal, 2000). Meaningful work is therefore considered as a spiritual dimension of large scope and benefits.

Previous empirical studies regarding the dimension of meaningful work reported its positive link with employee commitment. For example, Brown and Leigh (1996) found that the increase of meaningfulness and psycholgical safety of work fostered job involvement and enccouraged employees to invest entirely in their work roles. Milliman et al. (2003) found a positive link of meaningful work, as developed and measured by Ashmos and Duchon (2000), with job involvement and organizational commitment. Similar results were found by Pawar (2009) concerning job involvement, job satisfaction and organizational commitment, and by Rego and Cunha (2008a) regarding affective and normative commitment. Crawford et al. (2009) and Riasudeen and Prabavathy (2011), using the Milliman et al. (2003)'s measurement survey, found a positive and significant link of meaningful work with job involvement, intrinsic job satisfaction and organizational commitment.

Thus, it is expected that this spiritual dimension will be positively linked to employee commitment and this association will be of greater importance with a job-focus commitment, hereafter job involvement.

H1a. Meaningful work will be positively linked to job involvement. 
H1b. Meaningful work will be positively linked to group commitment.

H1c. Meaningful work will be positively linked to organizational commitment.

\subsubsection{Group Level: Sense of Community and Employee Commitment}

The second key dimension of WS referred to sense of community which is evaluated at the group level. It describes a work environment where employees feel part of a family through authentic and caring relationships (Fry et al., 2005; Milliman et al., 2003). Neal (2000) described this dimension as the "team spirit" since it embodies deep connections amongst group members mentally, emotionally and spiritually. The sense of community dimension emphasizes the high quality of connection and positive social relationships between group members (Dutton \& Heaphy 2003; Pfeffer, 2010). Thus, this spiritual dimension would then enhance employees' feelings of affiliation, satisfy their social needs and their overall happiness at the workplace (Rego \& Cunha, 2008b). In particular, the success of working teams and units requires this kind of feelings in order to endure the negative consequences of job and market pressure on teams' objectives (Dutton \& Heaphy 2003; Felps et al., 2006; Kozlowski \& Bell, 2012), and instead enhance loyalty and positive attitudes (Ellemers et al., 2004). Furthermore, using the Ashmos and Duchon (2000)'s measures, Duchon and Plowman (2005) found that differences in work unit community between multiple work units explained differences in their correspondant performance, and suggested that community building at the group level would be necessary to improve work unit productivity. Likewise, Milliman et al. (2003) found a positive and significant relationship of sense of community with organizational commitment, job involvement and organizational-based self esteem. Also, Crawford et al. (2009) and Riasudeen and Prabavathy (2011) provided further support for these findings. Hence, this spiritual dimension defined at the group level is assumed to be linked to employee commitment. In particular, the association is expected to be higher with a group-focused commitment, hereafter group commitment.

H2a. Sense of community will be positively linked to job involvement.

H2b. Sense of community will be positively linked to group commitment.

H2c. Sense of community will be positively linked to organizational commitment.

\subsubsection{Organizational Level: Organizational Values and Employee Commitment}

The third spiritual dimension is defined at the organisation level and referred to organizational values. These values embrace the company's meta-values which are linked to its mission and they are trusted and shared with all employees. As such, the alignment with the organizational values enhances the employees' feelings of belonging and attachment to their company (Kriger \& Hanson, 1999). Similarly, Kets de Vries (2001) holded that paying attention to meta-values that are worthy and compelling satisifies the employees' motivational need to belonging, attachement and enjoyment at work. These value-based organizations can be described as holding authentizotic qualities (i.e., vital to life) which allow the employees to explore the very best of them in matters of self-assertion, effectiveness and competency. Additionally, according to O'Reilly and Pfeffer (2000), value-based companies engage the hearts of their employees as much as their minds. Thus, 


\section{Macrothink}

International Journal of Human Resource Studies ISSN 2162-3058 2021, Vol. 11, No. 1

Kinjerski and Skrypnek (2006) reported via qualitative interviews with several participants that a compelling vision and mission provided their company with a strong organizational foundation and encouraged them to contribute more effectively and collectively. Milliman et al. (2003) and Rego and Cunha (2008a) provided empirical evidence of the benefits of organizational values, measured with Ashmos and Duchon (2000)'s survey, to different employee attitudes (e.g., organizational commitment, affective commitment and job satisfaction). Besides, Dvir et al. (2004) found that a meaningful vision of the company linked to its core values related positively to the affective commitment (emotional bond) and not to continuance commitment (calculative bond). Added to that, the spiritual dimension of organizational values has an impact on higher-order employee needs such as the search for meaning and deeper values in one's job and community (Milliman et al., 2017). Therefore, it is posited that organizational values will be positevely linked to employee commitment and, in particular, with an organization-focus commitment (e.g., organizational commitment).

H3a. Organizational values will be positively linked to job involvement.

H3b. Organizational values will be positively linked to group commitment.

H3c. Organizational values will be positively linked to organizational commitment.

Altogether, Figure 1 depicts the aformentioned multifocal framework and the underlying hypotheses associated with it:

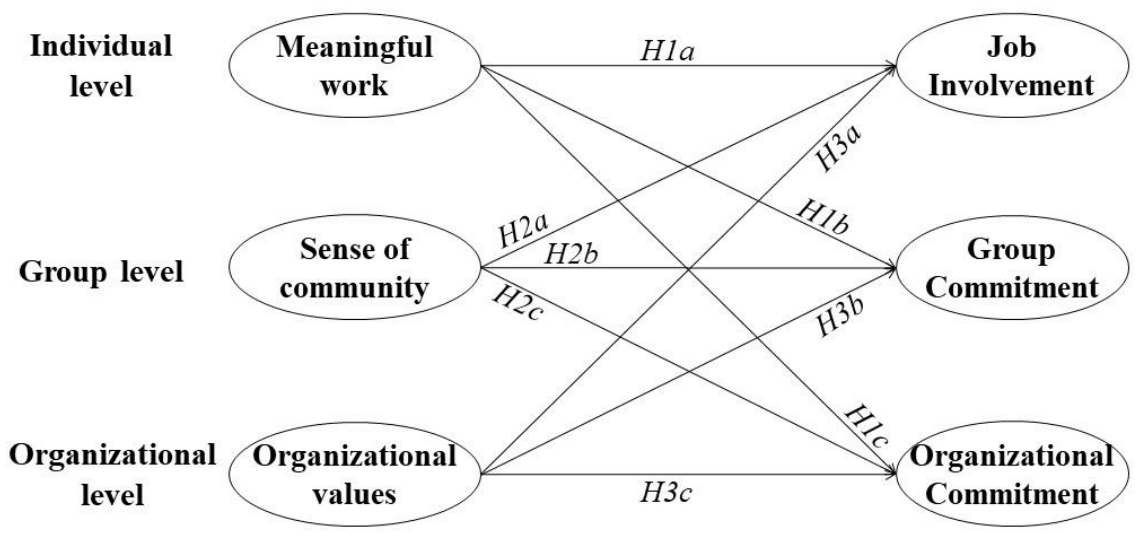

Figure 1. Research model

\section{Method}

\subsection{Sample and Procedure}

An online questionnaire was designed and sent to a random population in the Tunisian work context. A total number of 111 employees out of 350 filled the questionnaire, with only 2 responses excluded due to high rate of missing values. The final number of usable questionnaires $(N=111)$ represented a response-rate of $31.66 \%$. Table 1 shows the characteristics of this sample. 
Table 1. Sample characteristics

\begin{tabular}{|c|c|c|c|c|c|}
\hline$N=111$ & & & Tenure & $<1$ year & $20 \%$ \\
\hline \multirow[t]{2}{*}{ Gender } & Female & $58.52 \%$ & & $1-3$ years & $28.8 \%$ \\
\hline & Male & $41.48 \%$ & & $3-5$ years & $17.1 \%$ \\
\hline \multirow[t]{5}{*}{ Age } & $18-25$ & $8.31 \%$ & & 5-10 years & $24.3 \%$ \\
\hline & $26-35$ & $75 \%$ & & $>10$ years & $9.88 \%$ \\
\hline & $36-40$ & $9.5 \%$ & Position & Manager & $25.2 \%$ \\
\hline & $>40$ & $7.19 \%$ & & Administration & $22.4 \%$ \\
\hline & & & & Engineer-Technician & $30.6 \%$ \\
\hline \multirow[t]{3}{*}{ Education } & University & $98.16 \%$ & & Operator & $2.6 \%$ \\
\hline & High school & $1.84 \%$ & & Teacher & $2.2 \%$ \\
\hline & & & & Other & $17 \%$ \\
\hline
\end{tabular}

The proposed hypotheses of this study were tested with PLS-SEM analysis using SmartPLS 3 software. This statistical modeling technique is recommended as a causal-predictive approach for exploratory as well as explanatory research using latent (non-observable) variables (Hair et al., 2019). Besides, it was recommended to overcome the lack of statistical power in social and organization research since the PLS-SEM can generate a high statistical power for exploratory and developing research in particular (Hair et al., 2019; Sosik et al., 2009). The method overcomes the limits of mutliple regression models, which handle only direct observed variables, by combining a principal component analysis (for measurement models) with separate ordinaty least squares regressions (for structural models) to study the relationships between the latent unobserved variables (Hair et al., 2019; Mateos-Aparicio, 2011). The survey-based measurement of such latent variables in social and organization research, as for the filed of workplace spirituality and employee commitment, implies the presence of measurement errors which are not explicitly covered with multiple regression methods (Bollen \& Pearl, 2013; Mateos-Aparicio, 2011). Besides, given the purpose of the study was to explain the variation of commitment level through the variation of spiritual predictor variables (variables' effects test), the PLS seemed more convenient since it is a variance-based technique unlike the covariance-based SEM (model fitting test) (e.g., CB-SEM) (Gefen et al., 2000; Petter, 2018). Added to these facts is that the PLS-SEM method does not require large sample sizes or very restrictive assupmtions such as the multicolineariy between predictor variables, whose dependence relationships is particulary possible, or the lack of normality (Mateos-Aparicio, 2011). These issues can well be covered by the use of bias-corrected and accelerated bootstrapping (Bca) technique which should reduce the effect of data distributional concerns (Hair et al., 2019). For the present study, the sample size was then examined based on the required recommandations in PLS-SEM analysis (Cohen, 1988; Hair et al., 2014, p. 21) to ensure a minimum power analysis of 0.8 as recommended in statistical modelling. The sample size followed also the inverse square root method suggested by Kock and Hadaya (2018) for minimal sample size in PLS-SEM analysis. 


\subsection{Measures}

Employee commitment: this construct was subdivided into three commitment target-variables to account for the interest levels of this study (e.g., individual, group and organization). At the individual level, it was measured using four items adapted from the Job Involvement (JI) scale developed initially by Kanungo (1982) which focuses primarily on the psychological involvement with one's job and which is recommended in most multiple commitments research (Cohen, 2003). The four-item version of this scale was adopted by Milliman et al. (2003) who reported a single factor solution and satisfactory psychomertric characteristics. Some examples of these items are "I am very much involved personally in my job" and "I have very strong ties with my present job". At the group level, it was measured by the Group Commitment (GC) scale developed by Ellemers et al. (1998) which also reflects the sense of emotional involvement with the group. Sample items are "I am prepared to do additional chores, when this benefits my team" and "This team lies close to my heart". At the organizational level, it was measured using the Organizational Commitment (OC) scale developed by Mowday et al. (1979) (e.g., "I talk up this organization to my friends as a great organization to work for", "I am glad to tell others that I am part of this organization"). The six-item version of this scale comprises the positively worded items of the original scale which were also adopted by Milliman et al. (2003).

Workplace spirituality: this construct consisted of three dimensions. Meaningful work (MW) was measured with six items of the Ashmos and Duchon's (2000) scale ("I understand what gives my work personal meaning"; "My spirit in energized by work"). Sense of Community (SC) was measured using the seven-item scale adopted by Milliman et al. (2003) and inspired by Ashmos and Duchon (2000). Examples of these items are "I believe employees of my work unit genuenily care about each other" and "I feel there is sense of being part of a family in my work unit". The last spiritual dimension of Organizational Values (OV) was measured using eight items adopted by Ashmos and Duchon (2000) and Milliman et al. (2003), such as "I feel positive about the values of this organization" and "This organization is concerned about the health of those who work here".

All variables were self-reported and measured on 5-point Likert scale ranging from "Totally disagree" to "Totally agree". Given that, VIF values (Variance-Inflation-Factor) were calculated for all latent variables of the study using the full collinearity test proposed by Kock (2015) to check for Common Method Bias (CMB) in PLS-SEM analysis. The latter showed no CMB problem as all inner VIF values for each construct were below the threshold of 3.3 and 5 (see Table 2). Additionally, the Harman's single-factor test showed that the total variance extracted by one general latent factor equalled $43.657 \%$, which is below the cut-off of 50\% recommended by Podsakoff and Organ (1986). Overall psychometric properties of the measurement scales are given in Table 3. 
Table 2. Full test collinearity (Common method bias)

\begin{tabular}{lllllll}
\hline & 1 & 2 & 3 & 4 & 5 & 6 \\
\hline Meaningful work & & 4,534 & 4,617 & 3,507 & 4,314 & 3,951 \\
Sense of community & 2,779 & & 2,551 & 2,832 & 1,687 & 2,828 \\
Organizational values & 2,376 & 2,142 & & 2,295 & 2,369 & 2,133 \\
Job involvement & 3,232 & 4,259 & 4,110 & & 4,161 & 4,106 \\
Group commitment & 3,834 & 2,447 & 4,091 & 4,012 & & 4,063 \\
Organizational commitment & 3,219 & 3,760 & 3,377 & 3,630 & 3,725 & \\
\hline
\end{tabular}

Notes: Figures represent inner VIF values computed for all latent variables (LV) based on the full test collinearity (Kock, 2015) where all the LV (both endogenous and exogenous variables) were considered as potential predictors for each construct. All VIF were below the threshold of 3.3 and 5.

\section{Findings}

\subsection{Evaluation of the Measurement Models}

As suggested by Chin (2010), measurement models were assessed regarding their internal reliability, convergent and discriminant validity. The statistics concerning these tests are given in Table 3 and Table 4. First, all items loadings corresponding to each measured construct were above 0.6. Besides, the composite scale reliability (CSR) and the $\rho_{\mathrm{A}}$ exceeded 0.7 and fall below 0.95 as recommended by Hair et al. (2014). Thus, internal reliability of the measurement sclaes was validated. Second, the AVE values were above 0.5 indicating a good convergent validity. Third, discriminant validity was tested using the HTMT criterions as recommended by Henseler et al. (2014). All HTMT values were below the cut-off of 0.85 (see Table 4 below). Overall, all measurement models were validated with regard to their internal reliability, convergent and discriminant validity. 
Table 3. Psychometric properties of measurement scales

\begin{tabular}{|c|c|c|c|c|c|c|}
\hline & $\begin{array}{l}\text { Meaningful } \\
\text { work }\end{array}$ & $\begin{array}{l}\text { Sense of } \\
\text { community }\end{array}$ & $\begin{array}{l}\text { Organizational } \\
\text { values }\end{array}$ & $\begin{array}{l}\text { Job } \\
\text { involvement }\end{array}$ & $\begin{array}{l}\text { Group } \\
\text { Commitment }\end{array}$ & $\begin{array}{l}\text { Organizational } \\
\text { Commitment }\end{array}$ \\
\hline$\rho_{\mathrm{A}}$ & 0,916 & 0,906 & 0,909 & 0,831 & 0,907 & 0,944 \\
\hline CSR & 0,911 & 0,892 & 0,907 & 0,828 & 0,902 & 0,943 \\
\hline AVE & 0,632 & 0,549 & 0,551 & 0,547 & 0,570 & 0,734 \\
\hline MW1 & 0,793 & & & & & \\
\hline MW2 & 0,801 & & & & & \\
\hline MW3 & 0,796 & & & & & \\
\hline MW4 & 0,690 & & & & & \\
\hline MW5 & 0,761 & & & & & \\
\hline MW6 & 0,914 & & & & & \\
\hline SC1 & & 0,807 & & & & \\
\hline $\mathrm{SC} 2$ & & 0,579 & & & & \\
\hline $\mathrm{SC} 3$ & & 0,585 & & & & \\
\hline SC4 & & 0,638 & & & & \\
\hline SC5 & & 0,860 & & & & \\
\hline SC6 & & 0,874 & & & & \\
\hline SC7 & & 0,775 & & & & \\
\hline OV1 & & & 0,708 & & & \\
\hline OV2 & & & 0,824 & & & \\
\hline OV3 & & & 0,726 & & & \\
\hline OV4 & & & 0,762 & & & \\
\hline OV5 & & & 0,746 & & & \\
\hline OV6 & & & 0,643 & & & \\
\hline OV7 & & & 0,763 & & & \\
\hline OV8 & & & 0,752 & & & \\
\hline JI1 & & & & 0,675 & & \\
\hline JI2 & & & & 0,741 & & \\
\hline JI3 & & & & 0,801 & & \\
\hline JI4 & & & & 0,735 & & \\
\hline GC1 & & & & & 0,738 & \\
\hline GC2 & & & & & 0,874 & \\
\hline GC3 & & & & & 0,685 & \\
\hline GC4 & & & & & 0,743 & \\
\hline GC5 & & & & & 0,833 & \\
\hline GC6 & & & & & 0,749 & \\
\hline GC7 & & & & & 0,639 & \\
\hline $\mathrm{OC} 1$ & & & & & & 0,822 \\
\hline $\mathrm{OC} 2$ & & & & & & 0,826 \\
\hline $\mathrm{OC} 3$ & & & & & & 0,905 \\
\hline OC4 & & & & & & 0,890 \\
\hline OC5 & & & & & & 0,887 \\
\hline OC6 & & & & & & 0,805 \\
\hline
\end{tabular}

Notes: $\rho_{\mathrm{A}}=\mathrm{Rho} A$ (Internal reliability), $\mathrm{AVE}=$ Average Variance Extracted, $\mathrm{CSR}=\mathrm{Composite}$ Scale Reliability, MW= Meaningful work, $\mathrm{SC}=$ Sense of community, OV= Organizational values; JC: Job commitment; $\mathrm{GC}=$ Group Commitment; $\mathrm{OC}=$ Organizational Commitment 
Table 4. Measurement models evaluation (Results of convergent and discriminant validity)

\begin{tabular}{lllllll}
\hline & 1 & 2 & 3 & 4 & 5 & 6 \\
\hline Meaningful work & $\mathbf{0 , 6 3 2}$ & & & & & \\
Sense of community & 0,491 & $\mathbf{0 , 5 4 9}$ & & & & \\
Organizational values & 0,611 & 0,594 & $\mathbf{0 , 5 5 1}$ & & & \\
Job involvement & 0,849 & 0,541 & 0,658 & $\mathbf{0 , 5 4 7}$ & & \\
Group commitment & 0,723 & 0,773 & 0,612 & 0,724 & $\mathbf{0 , 5 7 0}$ & \\
Organizational & 0,811 & 0,511 & 0,690 & 0,786 & 0,688 & $\mathbf{0 , 7 3 4}$ \\
commitment & & & & & & \\
\hline
\end{tabular}

Notes: Figures below the diagonal represent HTMT values (Heterotrait-Heteromethod correlations, all correlations are below 0.9). Figures on diagonal represent each construct's AVE (all values are above 0.5).

\subsection{Evaluation of the Structural Model: Hypotheses Testing}

Figure 2 depicts the results of PLS analysis of the conceptual model where every path relationship corresponded to each of the hypotheses $H 1 a$ to $H 3 c$, respectively. The model was first checked for collinearity problem between predictor latent variables (Hair et al., 2014). As the inner VIF values were below the threshold of 3.3, no collinearity problem was then detected (see Table 5).

Table 5. Test for latent variables collinearity

\begin{tabular}{|c|c|c|c|}
\hline & Meaningful work & Sense of community & Organizational values \\
\hline Job involvement & 1,665 & 1,661 & 1,978 \\
\hline Group commitment & 1,665 & 1,661 & 1,978 \\
\hline $\begin{array}{l}\text { Organizational } \\
\text { commitment }\end{array}$ & 1,665 & 1,661 & 1,978 \\
\hline
\end{tabular}

Notes: Figures represent the inner VIF values obtained by PLS analysis. All values correspond to the cut-off of 3.3 .

Hence, after running the model, the estimates showed a positive and significant effect of meaningful work on both job involvement, group commitment and organizational commitment. Sense of community was only found linked positively and significantly to group commitment, but no significant effect was found on job involvement and organizational commitment. Organizational values were found only related positively and 
significantly to organizational commitment but not with job involvement nor group commitment (e.g., Table 6).

Table 6. Hypotheses testing results

\begin{tabular}{llllll}
\hline Hypotheses & Path coefficient & T-statistics & P-value & CI [2.5\%, 97.5\%] & Decision \\
\hline $\mathrm{H} 1 \mathrm{a}: \mathrm{MW} \rightarrow \mathrm{JI}$ & $\beta_{1 \mathrm{a}}=0.692$ & 7.602 & 0.000 & {$[0.515,0.848]$} & Supported \\
$\mathrm{H} 1 \mathrm{~b}: \mathrm{MW} \rightarrow \mathrm{GC}$ & $\beta_{1 \mathrm{~b}}=0.438$ & 4.430 & 0.000 & {$[0.246,0.613]$} & Supported \\
$\mathrm{H} 1 \mathrm{c}: \mathrm{MW} \rightarrow \mathrm{OC}$ & $\beta_{1 \mathrm{c}}=0.607$ & 8.020 & 0.000 & {$[0.441,0.738]$} & Supported \\
\hline $\mathrm{H} 2 \mathrm{a}: \mathrm{SC} \rightarrow \mathrm{JI}$ & $\beta_{2 \mathrm{a}}=0.078$ & 0.697 & 0.486 & {$[-0.129,0.312]$} & Not supported \\
$\mathrm{H} 2 \mathrm{~b}: \mathrm{SC} \rightarrow \mathrm{GC}$ & $\beta_{2 \mathrm{~b}}=0.554$ & 7.133 & 0.000 & {$[0.395,0.689]$} & Supported \\
$\mathrm{H} 2 \mathrm{c}: \mathrm{SC} \rightarrow \mathrm{OC}$ & $\beta_{2 \mathrm{c}}=0.040$ & 0.447 & 0.655 & {$[-0.132,0.192]$} & Not supported \\
\hline $\mathrm{H} 3 \mathrm{a}: \mathrm{OV} \rightarrow \mathrm{JI}$ & $\beta_{3 \mathrm{a}}=0.188$ & 1.525 & 0.128 & {$[-0.055,0.423]$} & Not supported \\
$\mathrm{H} 3 \mathrm{~b}: \mathrm{OV} \rightarrow \mathrm{GC}$ & $\beta_{3 \mathrm{~b}}=0.008$ & 0.076 & 0.940 & {$[-0.199,0.191]$} & Not supported \\
H3c: $\mathrm{OV} \rightarrow \mathrm{OC}$ & $\beta_{3 \mathrm{c}}=0.298$ & 3.211 & 0.001 & {$[0.125,0.504]$} & Supported \\
\hline
\end{tabular}

Notes: $\mathrm{MW}=$ Meaningful work, $\mathrm{SC}=$ Sense of community, $\mathrm{OV}=$ Organizational values; $\mathrm{JC}=$ Job commitment; $\mathrm{GC}=$ Group Commitment; $\mathrm{OC}=$ Organizational Commitment; $\mathrm{CI}=$ confidence interval Bias Corrected (Bootstrapping Bca).

Besides, the combined effects of the validated relationships, measured by the $\mathrm{R} 2$ adjusted coefficient were calculated for each commitment target variable to evaluate the predictive accuracy of the model (Ringle et al., 2018). Also, to evaluate more adequately the predictive power of the model, the Q2 values for each dependent variable were computed using PLSpredict approach (Shmueli et al., 2016) (e.g., Table 7). Furthermore, the above results pointed out differential effects between the studied spiritual predictors. For instance, sense of community and organizational values contributed exclusively to group commitment and organizational commitment, respectively, whereas meaningful work contributed to all commitment targets. Added to that, every predictor contributed largely to its presumed commitment target. Specifically, sense of community had the largest and only effect on group commitment, as organizational values had on organizational commitment. Similar findings were reported by Milliman et al. (2003) for the case of alignement of values which did not predict employee work attitudes (e.g., job involvment and intrinsic work satisfaction) over meaningful work and sense of community. However, meaningful work had largest effect successively on job involvement, organizational commitment and group commitment. In order to verify these findings, effect sizes were calculated after omitting each preditor successively from the model (Cohen, 1988) (e.g., Table 7). 
Table 7. $\mathrm{R}_{\text {adjusted, }}^{2} Q^{2}$ and Effect sizes $f^{2}$

\begin{tabular}{|c|c|c|c|c|}
\hline $\begin{array}{l}\text { Predicted } \\
\text { variable }\end{array}$ & $\mathrm{R}_{\text {adjusted }}^{2}$ & $Q^{2}$ & Predictors & Effect sizes $f^{2}$ \\
\hline \multirow[t]{3}{*}{ Job Involvement } & 0.745 & 0.565 & Meaningful work & 1.161 (large effect) * \\
\hline & & & Sense of community & 0.015 (small effect) \\
\hline & & & Organizational values & 0.072 (small effect) \\
\hline \multirow[t]{3}{*}{ Group commitment } & 0.746 & 0.617 & Meaningful work: & 0.466 (large effect) $*$ \\
\hline & & & Sense of community & 0.748 (large effect) $*$ \\
\hline & & & Organizational values & 0 (no effect) \\
\hline \multirow{3}{*}{$\begin{array}{l}\text { Organizational } \\
\text { commitment }\end{array}$} & 0.711 & 0.620 & Meaningful work & 0.787 (large effect) * \\
\hline & & & Sense of community & 0.003 (very small effect) \\
\hline & & & Organizational values & $0.160($ medium effect $) *$ \\
\hline
\end{tabular}

Notes: * the largest effect of the predictor variable on the presumed commitment variable. Meaningful work had largest effect on all commitment variables; Sense of community had largest effect on group commitment; Organizational values had largest effect on organizational commitment.

\section{Discussion}

As posited in this study, all spiritual dimensions were positively and significantly linked to multiple commitments. All hypothesis were then validated except for $H 2 a, H 2 c$ regarding relationships of sense of community with job involvement and organizational commitment, from one hand, and $H 3 a$ and $H 3 b$ regarding the links of organizational values with job involvement and group commitment from the other hand. These latter were not found significant in PLS analysis despite the positive correlation of sense of community and organizational values with all three commitment foci. These findings joined multiple studies on workplace spirituality and organizational commitment. For instance, Rego and Cunha (2008a) found a positive and significant links of three spiritual dimensions (sense of community, alignment of values and sense of contribution) with organizational commitment measured with Allen and Meyer's (1990) scale. Milliman et al. (2003) reported that three spiritual dimensions correlated positively with organizational commitment using the Mowday et al.'s (1979) measurement scale. In particular, they found that meaningful work and sense of community were linked to intrinsic work satisfaction and job involvement whereas organizational values linked only to organizational commitment. In sum, contribution of workplace spirituality dimensions to employee commitment was then confirmed by this study. Figure 2 below depicts the final model of the study. 


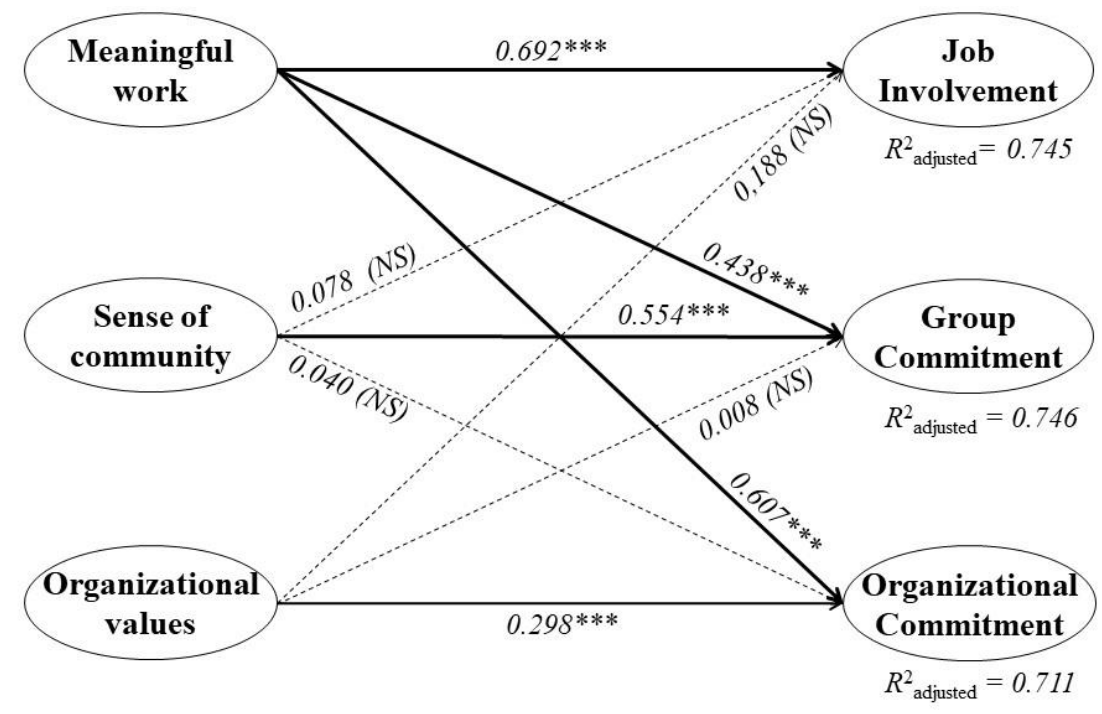

Notes: $N=111 . * p<0.05 ; * * * p<0.001 ; N S=$ Non-significant path. All VIF values (Variance-Inflation-Factor) for predictor latent variables are below the threshold of 3.3 (see Table V). Path arrows are stressed according to their relevance and significance.

Figure 2. Final model

In addition, as expected, each spiritual dimension was found linked differently to multiple commitments. For instance, organizational values, which pertain for value-based and authentic environment evaluated at the organizational level, had only the largest effect on organizational commitment. Likewise, sense of community, reflecting high-quality inter-relationships, mutual care and deep connections with correspondent and immediate group members, contributed largely and only to group commitment. In contrast, only meaningful work was found related mostly to job involvement, in addition to group and organizational commitments as well. These findings can be emphasized and explained with respect to the theoretical background exposed earlier. Hence, as suggested by self-concept and identity theories (Burke \& Reitzes, 1991; Oyserman, 2007; Shamir, 1991), employees tend to have different commitment orientation depending on their chronic self-identity which determine how the employees define themselves within the company, either at organization, group or individual levels (Johnson et al., 2010). Besides, the strength of and the tendency towards one particular foci of commitment would depend on the perceived interaction between the individual and the situational and environmental characteristics of the correspondent foci. These interactions were assessed in this study through the spiritual dimensions of organizational values, sense of community and meaningful work for three commitment foci (job involvement, group commitment and organizational commitment).

Following this, on one hand, when individuals evaluated this interaction more positively in terms of collective and relational ways (e.g., the organization and group levels), they were likely to be committed to a target relevant to these levels, which represented in this study the organizational and group commitments. These commitment targets were then mostly determined by the spiritual dimensions of organizational values and sense of community, respectively. On the other hand, when this interaction was evaluated positively at the 
individual level, employees were likely to be self-based committed. That is, they try to emphasize their personal values, attitudes and benefits, even at the expense of others, and hence, they show more instrumental and calculated commitment rather than relational and group-based commitment (Johnson et al., 2010, p. 234) which was evidenced in this study by the job involvement orientation. Similarly, Ellemers et al. (1998) explained that individuals who seek personal desire to advance in one's professional path would be more focused on personal career commitment, as opposed to team-oriented commitment which emphasizes rather the team's interests and benefits. Hence, this particular commitment target was explained largely via the spiritual dimension of meaningful work which emphasized the tendency to overvalue meaningful and enjoyable work tasks to satisfy personal and spiritual needs.

Yet, the present study showed in addition that those individuals who perceived more favourably their working context in terms of personal meaning and experience of work role (e.g., sense of meaningful work) were oriented to other commitment targets (group and organization focused commitment). In support of this finding, according to Johnson et al. (2010, p. 236), individuals with strong individual-focused identity can yet expand their commitment to other foci (e.g., group or organization) if their personal and desired goals overlap those of the immediate group or the organization. In particular, employees in this case search for additional and extra socioemotional needs like the respect and the recognition of their team-members and the company. As described by Pratt and Ashforth (2003), satisfying these extra needs can promote the meaning at work via the need for belonging and membership within the teams and the company (e.g., group and organizational levels). In the same way, although individuals strive for their own success, the experience of meaningfulness suggests that they strive to meet others' success, too, including their team-members and organization (Milliman et al., 2017; Wrzesniewski \& Dutton 2001). Indeed, drawing on theory of purposeful work behavior, Barrick et al. (2012, p. 138) posited that work meaningfulness increases in importance when employees feel their actions are valuable and useful for the company or for broader interest (e.g., societal level), leading to greater psychological absorption and dedication and fully functioning individuals (Ryan \& Deci, 2001, p. 161). In the same vein, Lips-Wiersma and Wright (2012) demonstrated that meaningful work can be a dynamic and process-oriented construct which focuses both on the self and the others (e.g., colleages and team-members). Overall, these assumptions were confirmed by the positive and significant relationship of meaningful work with all commitment foci. Indeed, this particular spiritual mindset appeals also a sense of calling and a "transcendental meaning" (Vandenberghe, 2011), which advocates for higher-order values of work-meaning and expands its limits to reach others, organization and life in general. Besides, several scholars have agreed on the fact that the search for meaning represents the quentessential stone of WS (Ashar \& Lane-Maher, 2004; Krishnakumar \& Neck, 2002).

Also, with regard to theory and commitment strategies implications, these results can inform more adequate linkages which enable an optimal fit of spiritual enviornment attributes with commitment targets. For example, companies should encourage employees to pursue their personal higher-order values and goals by enabling the best conditions for meaningful work 
(e.g., listening and satisfying the employees' needs and expectations towards their job, providing opportunities for self-expression and contribution), since this has substantial value added for individual outcomes (job involvement and other potential correlates like personal growth, individual performance, sense of contribution and career advancement), but also for group and organizational outcomes as well (e.g., work unit, global and complete performance). As posited by Kets de Vries (2001), companies who promoted the meaning need system inside their work context were considered as the best functioning companies whose employees are willing to go beyond expectations. Therefore, in this sense, meanignful work can be considered as a unique spiritual component that can be developed and used for multiple work conditions and strategies. Besides, given the importance of other commitments like group and organizational commitments, in particular for situations where group and organizational cohesiveness is most needed (e.g., project-based strategies, research and development strategies; or during certain circumstances like market crisis, low performance periods, transition periods, etc.), the company should invest in developing the company and teams' values and missions in line with the individual and personal values. This should enhance employees' sense of attraction and endorsment towards what is most important for the company and teams, besides its importance to them individually. For example, in certain circumstances (e.g., market crisis, special work projects, company social mission, etc.), some individuals believe more in the company or work unit's values and mission beyond what they feel about their work tasks, and so feel more attracted and committed to these targets (Milliman et al., 2017). These plausible two-way interactions of the individual self and the working environment may allow more possibilities for employees to express, organize and fulfill their needs for the best of them, their company and their life in general (Parker, 2014). HR practices can invest in that way to manage and increase the overall fit at the workplace while making the best fit at the personal individual level. Relatedly, as suggested by Milliman et al. (2017), these results provided support for the present spiritual framework as an extension or alternative of the multidimensional person-enviornment fit research. The authors discussed the assoiation between person-job fit with meaningful work, person-group fit with sense of community and person-organization fit with organizational values. In this way, these associations can be studied either as a mediating blocs or as an alternative framework for studying work environment fit with regard to different commitment variables or other related work outcomes (job performance, organizational citizenship, turnover intention). Also important is that this spiritual framework as a person-enviornment fit basis explained largely and homogenously all the studied commitment targets (job, group and organzizaion).

\section{Conclusion and Suggestions for Future Research}

The study of employee commitment has recently been challenged for a renewal in organizational and HRM studies. The employement relationship had to overcome its "hard" view of focusing on performance and liberate the employee voice (Arrowsmith \& Parker, 2013). Moreover, the decline of employee commitment should be considered, in a certain way, as an organizational "loss of faith" and hence calls for the study of personal and spiritual issues (Blenkinsopp, 2007).

Studied at three different levels (e.g., individual, group and organization), the present study 
reported that three-dimensional WS (meaningful work, sense of community and organizational values) contributed significantly to employee commitment. Besides, the study provided two main contributions to the multiple commitment research. First, the present spiritual framework provided a borader and more adequate emphasize on employees' needs in relation to employee commitment, as it was demonstrated that these spiritual dimensions contributed to and determined, about the same proportion, multiple commitments variance (e.g., job involvement, group commitment and organizational commitment). Thus, as suggested by Milliman et al. (2017, p. 4), this study asserted empirically the benefit of integrating workplace spirituality framework in the study of multiple employee commitment which specifically takes into account the interaction of employees' needs with the work enviornment attributes. Second, and more importantly, when the workplace adresses a more higher-order level of employees' needs fulfilment (e.g., self-transcendence, personal-growth, complete self-expression), implications go beyond self-interested and hedonic psychological interests. This was particularly evidenced by the substantial contribution of meaningful work to all commitment targets on which it had largest effect sizes (ranging from 0.466 to 1.161) unlike the contribution of organizational values and sense of community. Besides, the study demonstrated empirically the differential effects of workplace spirituality dimenions as suggested by several authors (Benefiel et al., 2014; Houghton et al., 2016). Yet, despite their contribution to multiple commitments, each spiritual dimension showed a specific link with a particular commitment level. For instance, based on effect sizes, the study reported a higher effect of each spiritual dimension on the presumed commitment target.

Finally, given that this study was limited to the direct relationship of workplace spirituality dimensions with specific commitment types and examined only three levels of analysis (e.g., individual, group and organization), further evaluation of individual-supervisory and individual-group relationships seems also needed. For instance, though its importance, the role of sense of community was not clearly evidenced in this study compared to other predictors (e.g., meaningful work), suggesting the use of other moderating or mediating variables as proposed by Oh et al. (2014) who reported a significant impact of culture for the case of these relationships in particular. Thus, future studies can evaluate moderating and/or mediating relationships and variables such as socialization processes, gender differences and leader-member exchange specifically for group, job and career outcomes. In addition, the study of interaction between different commitment targets can further be examined through different combinations of spiritual dimensions. This interaction is well supported in the multiple commitment research though the concerns raised for redundancy issues between commitment types (Cohen, 2003).

\section{References}

Allen, N. J., \& Meyer, J. P. (1990). The measurement and antecedents of affective, continuance and normative commitment to the organization. Journal of Occupational Psychology, 63(1), 1-18. https://doi.org/10.1111/j.2044-8325.1990.tb00506.x 
Arrowsmith, J., \& Parker, J. (2013). The meaning of 'employee engagement' for the values and roles of the HRM function. International Journal of Human Resource Management, 24(14), 2692-2712. https://doi.org/10.1080/09585192.2013.763842

Ashar, H., \& Lane-Maher, M. (2004). Success and spirituality in the new business paradigm. Journal of Management Inquiry, 13(3), 249-260. https://doi.org/10.1177/1056492604268218

Ashmos, D. P., \& Duchon, D. (2000). Spirituality at Work: A Conceptualization and Measure. Journal of Management Inquiry, 9(2), 134-145. https://doi.org/10.1177/105649260092008

Barrick, M., Mount, M., \& Li, N. (2012). The Theory of Purposeful Work Behavior: The Role of Personality, Higher-Order Goals, and Job Characteristics. Academy of Management Review, 38(1), 132-153. https://doi.org/10.5465/amr.10.0479

Benefiel, M., Fry, L. W., \& Geigle, D. (2014). Spirituality and religion in the workplace: History, theory, and research. Psychology of Religion and Spirituality, 6(3), 175-187. https://doi.org/10.1037/a0036597

Blenkinsopp, J. (2007). Organisational loss of faith: Treating affective commitment as a spiritual matter. Journal of Management, Spirituality and Religion, 4(2), 212-233. https://doi.org/10.1080/14766080709518658

Bollen, K. A., \& Pearl, J. (2013). Eight Myths About Causality and Structural Equation Models. https://doi.org/10.1007/978-94-007-6094-3_15

Brewer, M. B., \& Gardner, W. (1996). Who Is This 'We'? Levels of Collective Identity and Self Representations. Journal of Personality and Social Psychology, 71(1), 83-93. https://doi.org/10.1037/0022-3514.71.1.83

Brown, S. P., \& Leigh, T. W. (1996). A new look at psychological climate and its relationship to job involvement, effort, and performance. Journal of Applied Psychology, 81(4), 358-368. https://doi.org/10.1037/0021-9010.81.4.358

Burke, P. J., \& Reitzes, D. C. (1991). An Identity Theory Approach to Commitment. Social Psychology Quarterly, 54(3), 239. https://doi.org/10.2307/2786653

Chin, W. W. (2010). How to Write Up and Report PLS Analyses. In Handbook of Partial Least Squares (pp. 655-690). https://doi.org/10.1007/978-3-540-32827-8_29

Cohen J. (1988). Statistical Power Analysis for the Behavioural Science (2nd Edition). In Statistical Power Anaylsis for the Behavioral Sciences.

Cohen, A. (2003). Multiple commitments in the workplace: An integrative approach. In Multiple Commitments in the Workplace: An Integrative Approach. https://doi.org/10.4324/9781410607423

Crawford, A., Hubbard, S. S., Lonis-Shumate, S. R., \& O'neill, M. (2009). Workplace spirituality and employee attitudes within the lodging environment. Journal of Human Resources in Hospitality and Tourism, 8(1), 64-81. https://doi.org/10.1080/15332840802274445 
Dehler, G. E., \& Welsh, M. A. (1994). Spirituality and Organizational Transformation: Implications for the New Management Paradigm. Journal of Managerial Psychology, 9(6), 17-26. https://doi.org/10.1108/02683949410070179

Delbecq, A. L. (2013). Management, spirituality, and religion: Where do we go from here? In Handbook of Faith and Spirituality in the Workplace: Emerging Research and Practice. https://doi.org/10.1007/978-1-4614-5233-1_37

Dhiman, S., \& Marques, J. (2011). The role and need of offering workshops and courses on workplace spirituality. Journal of Management Development, 30(9), 816-835. https://doi.org/10.1108/02621711111164312

Duchon, D., \& Plowman, D. A. (2005). Nurturing the spirit at work: Impact on work unit performance. Leadership Quarterly, 16(5), 807-833. https://doi.org/10.1016/j.leaqua.2005.07.008

Dutton, J., \& Heaphy, E. (2003). The Power of High-Quality Connections. Positive Organizational Scholarship: Foundations of a New Discipline. https://doi.org/10.1017/CBO9781107415324.004

Dvir, T., Kass, N., \& Shamir, B. (2004). The emotional bond: Vision and organizational commitment among high-tech employees. Journal of Organizational Change Management, 17(2), 126-143. https://doi.org/10.1108/09534810410530575

Ellemers, N., De Gilder, D., \& Haslam, S. A. (2004). Motivating individuals and groups at work: A social identity perspective on leadership and group performance. Academy of Management Review, 29(3), 459-478. https://doi.org/10.5465/AMR.2004.13670967

Ellemers, N., De Gilder, D., \& Van Den Heuvel, H. (1998). Career-Oriented Versus Team-Oriented Commitment and Behavior at Work. Journal of Applied Psychology, 83(5), 717-730. https://doi.org/10.1037/0021-9010.83.5.717

Felps, W., Mitchell, T. R., \& Byington, E. (2006). How, When, and Why Bad Apples Spoil the Barrel: Negative Group Members and Dysfunctional Groups. Research in Organizational Behavior, 27, 175-222. https://doi.org/10.1016/S0191-3085(06)27005-9

Fry, L. W., Vitucci, S., \& Cedillo, M. (2005). Spiritual leadership and army transformation: Theory, measurement, and establishing a baseline. Leadership Quarterly, 16(5), 835-862. https://doi.org/10.1016/j.leaqua.2005.07.012

Gefen, D., Straub, D., \& Boudreau, M.-C. (2000). Structural Equation Modeling and Regression: Guidelines for Research Practice. In Communications of the Association for Information Systems (Vol. 4). https://doi.org/10.17705/1cais.00407

Greguras, G. J., \& Diefendorff, J. M. (2009). Different Fits Satisfy Different Needs: Linking Person-Environment Fit to Employee Commitment and Performance Using Self-Determination Theory. Journal of Applied Psychology, 94(2), 465-477. https://doi.org/10.1037/a0014068 
Guevara, K., \& Ord, J. (1996). The search for meaning in a changing work context. Futures, 28(8), 709-722. https://doi.org/10.1016/0016-3287(96)00030-4

Gull, G. A., \& Doh, J. (2004). The 'transmutation' of the organization: Toward a more spiritual workplace. Journal of Management Inquiry, 13(2), 128-139. https://doi.org/10.1177/1056492604265218

Hair, J. F., Hult, G. T. M., Ringle, C. M., \& Sarstedt, M. (2014). A primer on Partial least squares structural equation modeling (PLS-SEM). In Sage Publisher. https://doi.org/10.1108/EBR-10-2013-0128

Hair, J. F., Risher, J. J., Sarstedt, M., \& Ringle, C. M. (2019). When to use and how to report the results of PLS-SEM. European Business Review. https://doi.org/10.1108/EBR-11-2018-0203

Henseler, J., Ringle, C. M., \& Sarstedt, M. (2014). A new criterion for assessing discriminant validity in variance-based structural equation modeling. Journal of the Academy of Marketing Science, 43(1), 115-135. https://doi.org/10.1007/s11747-014-0403-8

Houghton, J. D., Neck, C. P., \& Krishnakumar, S. (2016). The what, why, and how of spirituality in the workplace revisited: a 14-year update and extension. Journal of Management, Spirituality and Religion, 13(3), 177-205. https://doi.org/10.1080/14766086.2016.1185292

Joelle, M., \& Coelho, A. M. (2019). The impact of spirituality at work on workers' attitudes and individual performance. International Journal of Human Resource Management, 30(7), 1111-1135. https://doi.org/10.1080/09585192.2017.1314312

Johnson, R. E., \& Chang, C. H. (2006). 'I' is to continuance as 'We' is to affective: The relevance of the self-concept for organizational commitment. Journal of Organizational Behavior, 27(5), 549-570. https://doi.org/10.1002/job.364

Johnson, R. E., Chang, C. H., \& Yang, L. Q. (2010). Commitment and motivation at work: The relevance of employee identity and regulatory focus. Academy of Management Review, 35(2), 226-245. https://doi.org/10.5465/AMR.2010.48463332

Kanungo, R. N. (1982). Measurement of job and work involvement. Journal of Applied Psychology, 67(3), 341-349. https://doi.org/10.1037/0021-9010.67.3.341

Kets De Vries, M. F. R. (2001). Creating authentizotic organizations: Well-functioning individuals in vibrant companies. Human Relations, 54(1), 101-111. https://doi.org/10.1177/0018726701541013

Kinjerski, V., \& Skrypnek, B. J. (2006). Creating organizational conditions that foster employee spirit at work. Leadership and Organization Development Journal, 27(4), 280-295. https://doi.org/10.1108/01437730610666037

Klein, H. J., Molloy, J. C., \& Brinsfield, C. T. (2012). Reconceptualizing workplace commitment to redress a stretched construct: Revisiting assumptions and removing confounds. Academy of Management Review, 37(1), 130-151. https://doi.org/10.5465/amr.2010.0018 
Knapp, J. R., Diehl, M. R., \& Dougan, W. (2020). Towards a social-cognitive theory of multiple psychological contracts. European Journal of Work and Organizational Psychology, 29(2), 200-214. https://doi.org/10.1080/1359432X.2019.1709538

Kock, N. (2015). Common method bias in PLS-SEM: A full collinearity assessment approach. International Journal of E-Collaboration, 11(4), 1-10. https://doi.org/10.4018/ijec.2015100101

Kock, N., \& Hadaya, P. (2018). Minimum sample size estimation in PLS-SEM: The inverse square root and gamma-exponential methods. Information Systems Journal, 28(1), 227-261. https://doi.org/10.1111/isj.12131

Kozlowski, S. W. J., \& Bell, B. S. (2012). Work Groups and Teams in Organizations. In Handbook of Psychology, Second Edition. https://doi.org/10.1002/9781118133880.hop212017

Krahnke, K., Giacalone, R. A., \& Jurkiewicz, C. L. (2003). Point-counterpoint: Measuring workplace spirituality. Journal of Organizational Change Management, 16(4), 396-405. https://doi.org/10.1108/09534810310484154

Kriger, M. P., \& Hanson, B. J. (1999). A value-based paradigm for creating truly healthy organizations. Journal of Organizational Change Management, 12(4), 302-317. https://doi.org/10.1108/09534819910282144

Krishnakumar, S., \& Neck, C. P. (2002). The "what", "why" and "how" of spirituality in the workplace. Journal of Managerial Psychology, 17(3), 153-164. https://doi.org/10.1108/02683940210423060

Kristof-Brown, A. L., Zimmerman, R. D., \& Johnson, E. C. (2005). Consequences of individuals' fit at work: A meta-analysis of person-job, person-organization, person-group, and person-supervisor FIT. Personnel Psychology, 58(281-342). https://doi.org/10.1111/j.1744-6570.2005.00672.x

Lapointe, E., Vandenberghe, C., Ben Ayed, A. K., Schwarz, G., Tremblay, M., \& Chenevert, D. (2019). Social Comparisons, Self-Conceptions, and Attributions: Assessing the Self-Related Contingencies in Leader-Member Exchange Relationships. Journal of Business and Psychology, 35, 381-402. https://doi.org/10.1007/s10869-019-09628-9

Lips-Wiersma, M., \& Wright, S. (2012). Measuring the Meaning of Meaningful Work: Development and Validation of the Comprehensive Meaningful Work Scale (CMWS). Group and Organization Management, 37(5), 655-685. https://doi.org/10.1177/1059601112461578

Mateos-Aparicio, G. (2011). Partial least squares (PLS) methods: Origins, evolution, and application to social sciences. Communications in Statistics - Theory and Methods, 40(13), 2305-2317. https://doi.org/10.1080/03610921003778225

Meyer, J. P. (2016). Handbook of employee commitment. In Handbook of Employee Commitment. https://doi.org/10.4337/9781784711740 
Meyer, J. P., \& Allen, N. J. (1991). A three-component conceptualization of organizational commitment. Human Resource Management Review, 1(1), 61-89. https://doi.org/10.1016/1053-4822(91)90011-Z

Meyer, J. P., Stanley, D. J., Herscovitch, L., \& Topolnytsky, L. (2002). Affective, continuance, and normative commitment to the organization: A meta-analysis of antecedents, correlates, and consequences. Journal of Vocational Behavior, 61(1), 20-52. https://doi.org/10.1006/jvbe.2001.1842

Milliman, J., Czaplewski, A. J., \& Ferguson, J. (2003). Workplace spirituality and employee work attitudes: An exploratory empirical assessment. Journal of Organizational Change Management, 16(4), 426-447. https://doi.org/10.1108/09534810310484172

Milliman, J., Gatling, A., \& Bradley-Geist, J. C. (2017). The implications of workplace spirituality for person-environment fit theory. Psychology of Religion and Spirituality, 9(1), 1-12. https://doi.org/10.1037/rel0000068

Mitroff, I. I. (2003). Do not promote religion under the guise of spirituality. Organization, 10(2), 375-382. https://doi.org/10.1177/1350508403010002011

Mitroff, I., \& Denton, E. (1999). A Study of Spirituality in the Workplace. Sloan Management Review, 40(4), 83-92.

Mowday, R. T., Steers, R. M., \& Porter, L. W. (1979). The measurement of organizational commitment. Journal of Vocational Behavior, 14(2), 224-247. https://doi.org/10.1016/0001-8791(79)90072-1

Neal, J. (2000). Work as service to the Divine: Giving our gifts selflessly and with joy. American Behavioral Scientist, 8, 1316-1333. https://doi.org/10.1177/00027640021955883

Oh, I. S., Guay, R. P., Kim, K., Harold, C. M., Lee, J. H., Heo, C. G., \& Shin, K. H. (2014). Fit happens globally: A meta-analytic comparison of the relationships of person-environment fit dimensions with work attitudes and performance across East Asia, Europe, and North America. Personnel Psychology, 67(1), 99-152. https://doi.org/10.1111/peps.12026

O'Reilly, C. A., \& Pfeffer, J. (2000). Unlocking the hidden value in organizations. Employment Relations Today, 27(2), 63-80. https://doi.org/10.1002/ert.3910270208

Oyserman, D. (2007). Self-Concept and Identity. In Blackwell Handbook of Social Psychology: Intraindividual Processes. https://doi.org/10.1002/9780470998519.ch23

Parker, S. K. (2014). Beyond Motivation: Job and Work Design for Development, Health, Ambidexterity, and More. Annual Review of Psychology, 65, 661-691. https://doi.org/10.1146/annurev-psych-010213-115208

Pawar, B. S. (2009). Individual spirituality, workplace spirituality and work attitudes: An empirical test of direct and interaction effects. Leadership and Organization Development Journal, 30 . 
Petter, S. (2018). 'Haters Gonna Hate': PLS and Information Systems Research. The DATABASE for Advances in Information Systems, 49(2), 10-13. https://doi.org/10.1145/3229335.3229337

Pfeffer, J. (2010). Business and the spirit: Management practices that sustain values. In Handbook of Workplace Spirituality and Organizational Performance.

Podsakoff, P. M., \& Organ, D. W. (1986). Self-Reports in Organizational Research: Problems and Prospects. Journal of Management, 12(4), 531-544. https://doi.org/10.1177/014920638601200408

Pratt, M. G., \& Ashforth, Blake, E. (2003). Fostering meaningfulness in working and at work. Positive Organizational Scholarship: Foundations of a New Discipline, 309-327.

Rego, A., \& Cunha, M. P. e. (2008). Authentizotic climates and employee happiness: Pathways to individual performance? Journal of Business Research, 61(7), 739-752. https://doi.org/10.1016/j.jbusres.2007.08.003

Rego, A., \& Cunha, M. P. e. (2008). Workplace spirituality and organizational commitment: An empirical study. Journal of Organizational Change Management, 21(1), 53-75. https://doi.org/10.1108/09534810810847039

Riasudeen, S., \& Prabavathy, R. (2011). Relationship of workplace spirituality and work attitude in manufacturing organisation. Global Management Review, 5(4), 29-37.

Ringle, C. M., Sarstedt, M., Mitchell, R., \& Gudergan, S. P. (2018). Partial least squares structural equation modeling in HRM research. International Journal of Human Resource Management, 31(12), 1617-1643. https://doi.org/10.1080/09585192.2017.1416655

Ryan, R. M., \& Deci, E. L. (2001). On Happiness and Human Potentials: A Review of Research on Hedonic and Eudaimonic Well-Being. Annual Review of Psychology, 52, 141-166. https://doi.org/10.1146/annurev.psych.52.1.141

Shamir, B. (1991). Meaning, Self and Motivation in Organizations. Organization Studies, 12(3), 405-424. https://doi.org/10.1177/017084069101200304

Shmueli, G., Ray, S., Velasquez Estrada, J. M., \& Chatla, S. B. (2016). The elephant in the room: Predictive performance of PLS models. Journal of Business Research, 69(10), 4552-4564. https://doi.org/10.1016/j.jbusres.2016.03.049

Singhal, M., \& Chatterjee, L. (2006). A person-organization fit-based approach for spirituality at work: Development of a conceptual framework. Journal of Human Values, 12(2), 161-178. https://doi.org/10.1177/097168580601200205

Sosik, J. J., Kahai, S. S., \& Piovoso, M. J. (2009). Silver bullet or voodoo statistics?: A primer for using the partial least squares data analytic technique in group and organization research. Group and Organization Management, 34(1), 56. https://doi.org/10.1177/1059601108329198 


\section{Macrothink}

International Journal of Human Resource Studies

ISSN 2162-3058 2021, Vol. 11, No. 1

Van Den Heuvel, M., Demerouti, E., Schreurs, B. H. j., Bakker, A. B., \& Schaufeli, W. B. (2009). Does meaning-making help during organizational change?: Development and validation of a new scale. Career Development International, 14(6), 508-533. https://doi.org/10.1108/13620430910997277

Van Rossenberg, Y. G. T., Klein, H. J., Asplund, K., Bentein, K., Breitsohl, H., Cohen, A., ... Yalabik, Z. Y. (2018). The future of workplace commitment: key questions and directions. European Journal of Work and Organizational Psychology, 27(2), 153-167. https://doi.org/10.1080/1359432X.2018.1443914

Vandenberghe, C. (2011). Workplace spirituality and organizational commitment: An integrative model. Journal of Management, Spirituality and Religion, 8(3), 211-232. https://doi.org/10.1080/14766086.2011.599146

Wagner-Marsh, F., \& Conley, J. (1999). The fourth wave: The spiritually-based firm. Journal of Organizational Change Management, 12(4), 292-301. https://doi.org/10.1108/09534819910282135

Wrzesniewski, A., \& Dutton, J. E. (2001). Crafting a job: Revisioning employees as active crafters of their work. Academy of Management Review, 26(2), 179-201. https://doi.org/10.5465/AMR.2001.4378011

\section{Copyright Disclaimer}

Copyright for this article is retained by the author(s), with first publication rights granted to the journal.

This is an open-access article distributed under the terms and conditions of the Creative Commons Attribution license (http://creativecommons.org/licenses/by/4.0/). 